\title{
A Trend Analysis of Private Label Research Between 2000 and 2012
}

\author{
Sebastian Molinillo ${ }^{\mathrm{a}}$, Yuksel Ekinci ${ }^{\mathrm{b}}$, Georgina Whyatt ${ }^{\mathrm{c}}$, \\ Nicoletta Occhiocupo ${ }^{\mathrm{d}}$
}

\author{
aAssociate Professor of Marketing, Universidad de Málaga, Andalucía Tech, Facultad de Ciencias \\ Económicas y Empresariales, smolinillo@uma.es \\ ${ }^{\mathrm{b}}$ Professor of Marketing, Faculty of Business, Oxford Brookes University, yekinci@brookes.ac.uk \\ ${ }^{c} \mathrm{Head}$ of the Department of Marketing, Faculty of Business, Oxford Brookes University, ge- \\ whyatt@brookes.ac.uk
}

${ }^{\mathrm{d}}$ Senior Lecturer, Faculty of Business, Oxford Brookes University, nocchiocupo@brookes.ac.uk

\begin{abstract}
The aim of this study is to review the state of empirical and theoretical research about Private Label (PL) and to identify gaps and future research avenues. This paper uses a bibliometric approach of recent advances in the research of PL; it focuses on the period of greatest scientific output (2000-2012) and includes all international publications on PL in marketing journals ranked by the Academic Journal Quality Guide. The analysis systematically considers main authors and universities, countries, topics of investigation and methodologies used. The result reveals that research on the topic has been strongly influenced by a small group of authors and that most studies come from United States, Spain, United Kingdom, Netherlands, France, Australia and Germany. The paper discusses key emerging topics on PL such as consumer perceptions and behaviour, price, channel relationships and quality. Most of the articles have been focused on grocery products using a quantitative approach. Directions for future research are suggested.
\end{abstract}

Keywords. Private label, Private brand, Store brand, Own-brand, Retail brand, Review.

\section{References}

Association of Business Schools (2010), “Academic Journal Quality Guide, Version 4”, available at: http://www.associationofbusinessschools.org (accessed $2^{\text {nd }}$ July 2012)

Bonwich, W. (1962), "Will private brands in nonfoods invade the supermarket industry - a nationwide survey", Journal of Retailing, Vol. 39 No. 2, pp. 29-33.

Brinberg, David L. and Joseph McGrath (1985), Validity and the Research Process, Beverly Hills, CA: Sage Publications.

Callon, M, Courtial, J.P. and Penan, H. (1995), Cienciometría. El estudio cuantitativo de la actividad científica: de la bibliometría a la vigilancia tecnológica. Ediciones Trea, Gijón.

Egghe, L. (2006), "Theory and practise of the g-index", Scientometrics, October, Volume 69, Issue 1, pp 131-152.

Harzing, A.W. (2007), Publish or Perish, available from http://www.harzing.com/pop.htm 
Harzing, A.W. (2012), Journal Quality List, Forty-seventh Edition, 27 August 2012, Ed. by Professor Anne-Wil Harzing, University of Melbourne avalaible at http://www.harzing.com (accessed 29 January 2013).

Herstein R. and Gamliel E. (2004), An investigation of private branding as a global phenomenon", Journal of Euromarketing, Vol. 13 (4), pp.59-77.

Hirsch, J.E. (2005), “An index to quantify an individual's scientific research output", Proceedings of the National Academy of Sciences, Vol. 102 No. 46, pp. 16569-16572.

Hyman, M.R., Kopf, D.A. and Lee, D. (2010), "Review of literature - future research suggestions: Private label brands: Benefits, success factors and future research", Journal of Brand Management, Vol. 17 No. 5, pp. 368-389.

Leone, RP., Robinson, LM., Bragge, J. and Somervuori, O. (2012), “A citation and profiling analysis of pricing research from 1980 to 2010", Journal of Business Research, 65, pp. 10101024.

Leonidou, L.C., Barnes, B.R., Spyropoulou, S. and Katsikeas, C.S. (2010), “Assessing the contribution of leading mainstream marketing journals to the international marketing discipline", International Marketing Review, Vol. 27 No. 5, pp. 491-518.

Lotka, A.J. (1926), "The frequency distribution of scientific productivity", Journal of the Washington Academy of Sciences, Vol. 16 (12). pp. 317-323.

Malhotra, N.K., Wu, L. and Whitelock, J. (2013), “An updated overview of research published in the International Marketing Review 1983 to 2011”, International Marketing Review, Vol. 30 No. 1, pp. 7-20.

Manikandan, M. K. M. (2012), “Theory Building on Private Label Brands: A Literature Review", The IUP Journal of Brand Management, Vol. IX No. 2, pp. 64-77.

Nielsen (2011), "Global Private Label Report: The Rise of the Value-Conscious Shopper", available at: http://www.nielsen.com/us/en/newswire/2011/global-private-label-report-the-rise-ofthe-value-conscious-shopper.html (accessed $3^{\text {rd }}$ March 2014)

Private Label Manufacturers Association (2013), "Industry News", available at: http://www.plmainternational.com/industry-news/private-label-today (accessed $3^{\text {rd }}$ March 2014)

Stremersch S, Verniers I and Verhoef PC. (2007), "The quest for citations: drivers of article impact”, Journal of Marketing, 71(3), 171-193. 